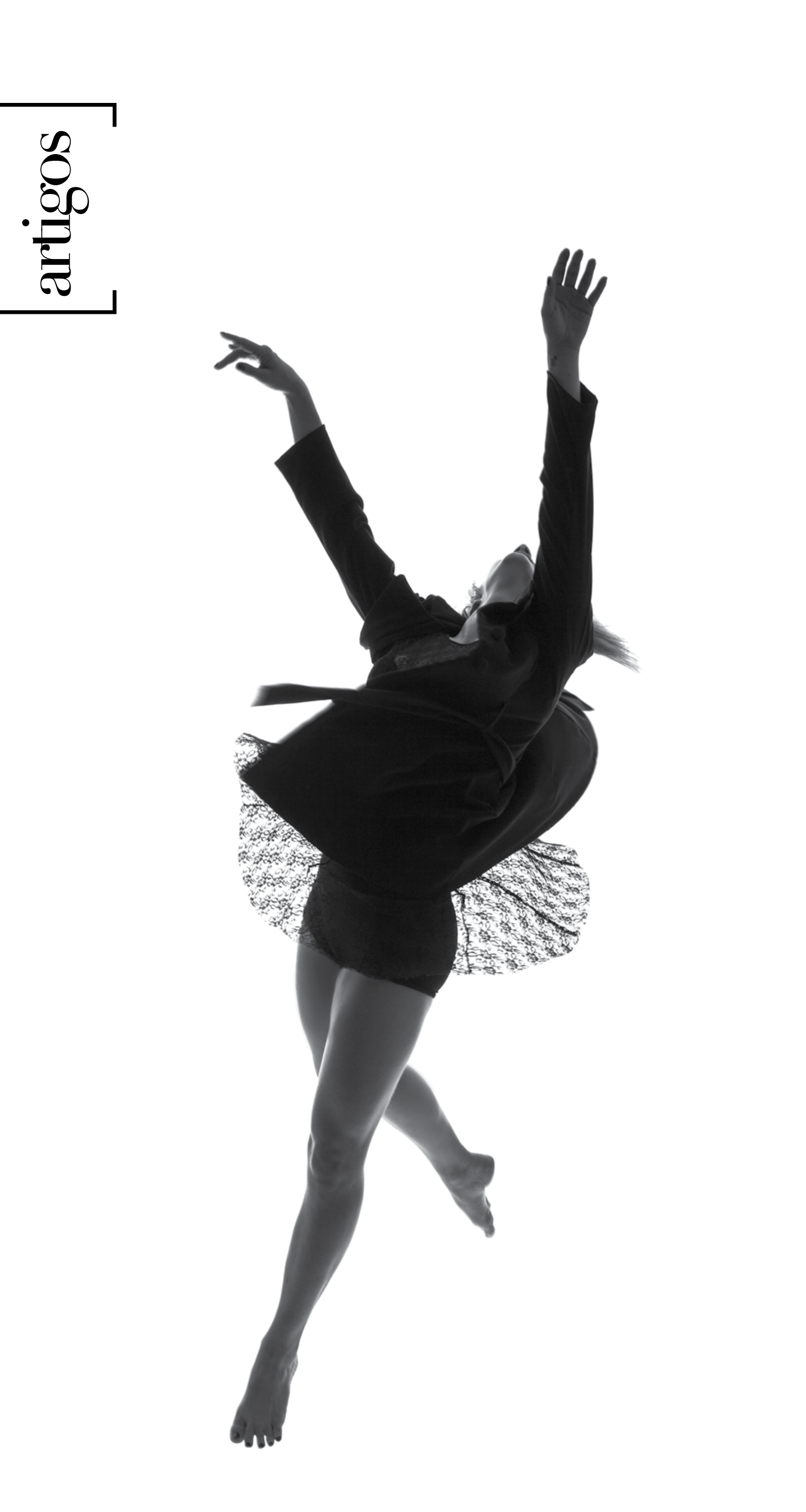



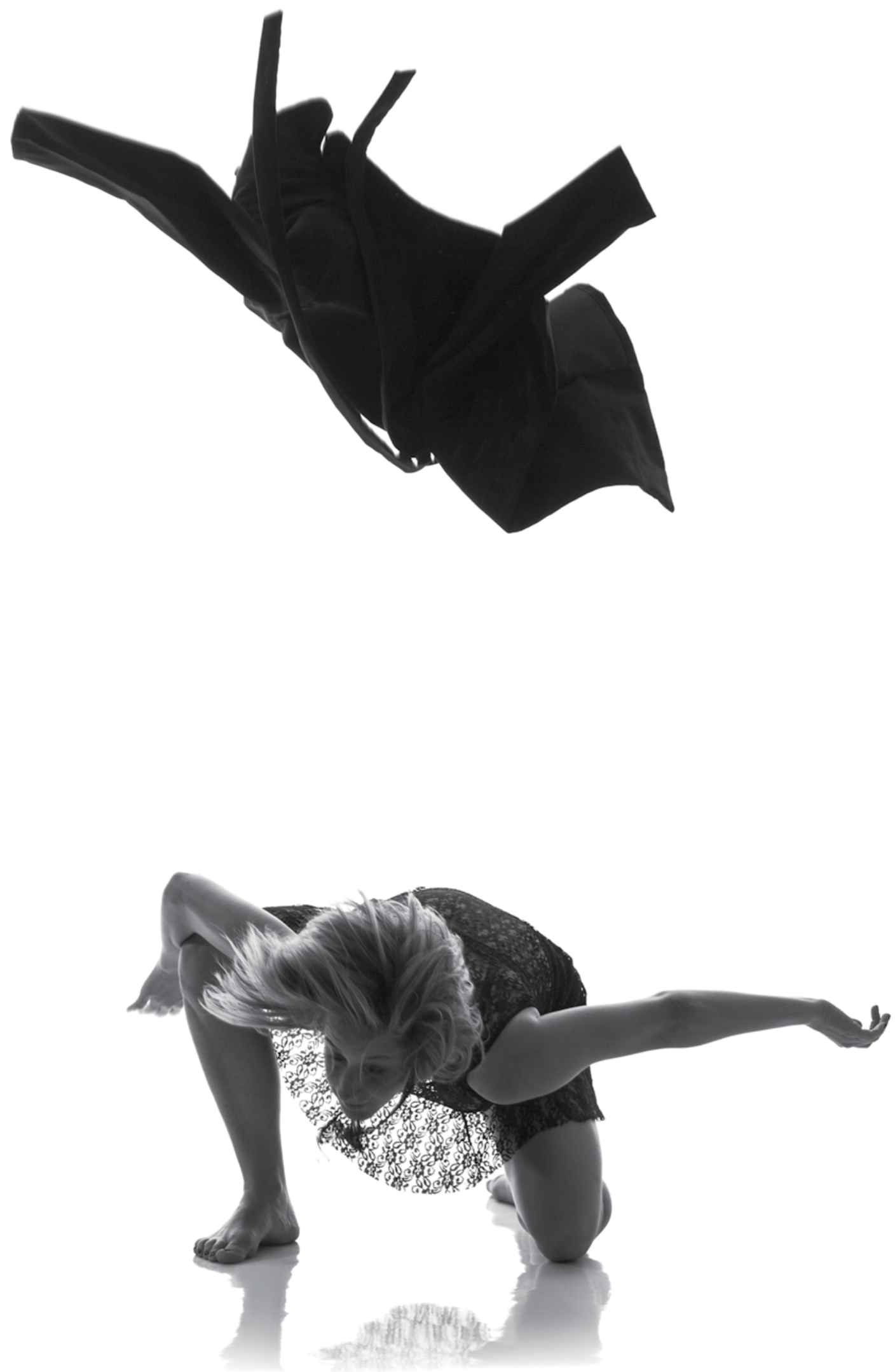
artigo $]$

[ GEANNETI TAVARES SALOMON ]

Doutoranda no Poslit UFMG; mestrado em Literaturas de Língua Portuguesa e graduação em Letras (PUC Minas); Estilismo e modelagem do vestuário (UFMG). Publicou Moda e ironia em Dom Casmurro (Alameda). Docente em Moda na UNA.

E-mail: gntavares@gmail.com

\title{
Moda e espionagem em El tiempo entre costuras, de María Dueñas'
}

\author{
Fashion and espionage in El tiempo entre \\ costuras, of María Dueñas
}

[resumo] El tiempo entre costuras é um romance da escritora espanhola María Dueñas que tem como fio narrativo a experiência da modista Sira Quiroga, como espiã, no período entre a Guerra Civil Espanhola e a Segunda Guerra Mundial. Este artigo procura levantar os principais elementos da trama que comprovam o papel da moda na construção das personagens e no enredo da obra, tendo como foco Sira Quiroga e Rosalinda Powel Fox, mais especificamente. A profissão de modista torna-se, no cenário de guerra, o álibi perfeito, a possibilidade de uma mulher se infiltrar nos ambientes estratégicos de planejamento de guerra, quase totalmente masculinos, sem trazer suspeitas. Também são observadas algumas personagens femininas em suas experiências particulares de guerra.

palavras-chave

moda; espionagem; literatura de guerra;

feminino.

[abstract] El tiempo entre costuras is a novel of the Spanish writer María Dueñas whose narrative thread is the experience of dressmaker Sira Quiroga, as a spy, between the Spanish Civil War and World War II. This article seeks to raise the main elements of the plot that prove the role of fashion in the construction of the characters and the plot of the work, focusing on Sira Quiroga and Rosalinda Powel Fox, more specifically. The dressmaker profession becomes, at the war scenario, the perfect alibi, the possibility of a woman to infiltrate into the strategic environments of war planning, almost entirely male, without bringing any suspicion. Are also observed some female characters in their particular war experiences.

[keywords] fashion; espionage; war literature; female. 
Nuestros destinos pudieron ser éstos o pudieron ser otros del

todo distintos porque lo que de nosotros fue en ningún sitio quedó recogido. Tal vez ni siquiera llegamos a existir. 0 quizá sí lo hicimos, pero nadie percibió nuestra presencia. Al fin y al cabo, nos mantuvimos siempre en el envés de la historia, activamente invisibles en aquel tiempo que vivimos entre costuras.

María Dueñas

El tiempo entre costuras

0 romance El tiempo entre costuras (2009), de María Dueñas, traduzido no Brasil como 0 tempo entre costuras, propõe-se a ser uma aventura, tendo como cenários os ateliês de alta-costura que vestiam as mulheres e amantes dos poderosos, os hotéis

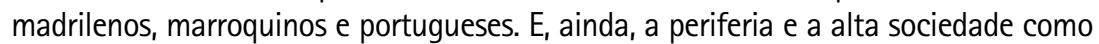
lugares em oposição, a espionagem e a conspiração política como redes sem saída e também uma trama que envolve as pessoas que não estavam no front da Guerra Civil Espanhola e da Segunda Guerra Mundial, mas no entorno dos conflitos. Trata-se de uma obra considerada como literatura de guerra por trazer a representação literária de conflitos que envolvem as guerras e, ainda, pelo foco de suas relações com a história e a memória cultural. É um romance com bases históricas, elaborado por uma pesquisadora acadêmica, professora de Filologia, que expõe uma justificativa de pesquisa por meio da inclusão de uma bibliografia no final do livro e de nota da autora. Por esses meios, explica seu processo de criação da obra e faz agradecimentos, apontando testemunhos de pessoas que a ajudaram a construir cenários e a reinventar personagens baseadas em pessoas reais da história da Espanha. Cita a ajuda de historiadores, como no caso de Mohamed Ibn Azzuz, que permitiu uma proximidade mais real à vida de Juan Luis Beigbeder, ministro de Assuntos Exteriores do primeiro franquismo, e também Domingo Del Pino, no caso de Rosalinda Powell Fox, amante de Beigbeder, peça-chave na argumentação do romance. Importante também dizer que o romance foi adaptado e produzido como série para o canal espanhol Antena 3, com grande sucesso de audiência.

Este artigo não pretende discutir as relações tênues entre obra ficcional e obra biográfica, mas será impossivel não esbarrar nas perspectivas da história e da memória como construções. Também não é intenção abordar as ligações entre o real e 0 imaginário, no que concerne ao posicionamento do que é real ou do que é ficcional, percebendo que na economia do romance isso fica quase indistinto para o leitor, exceto por algumas partes postas em questão por outros autores. ${ }^{2}$

Pretende-se trazer um recorte sobre o envolvimento da protagonista Sira Quiroga na espionagem de guerra, o que se torna possivel a partir da presença da moda no romance, visto que a personagem é modista e tem sua construção baseada nesse universo, tornando-se esse um dos pontos de apoio da narrativa. Também será abordado o uso de ambientes femininos como local de busca de informação e espionagem durante os periodos de conflito - a Guerra Civil Espanhola e a Segunda Guerra Mundial e a posição das mulheres nessas situações refletidas no romance, já que se trata de um romance com bases históricas comprovadas, trazendo também uma discussão sobre gênero. Também perpassaremos pela relação da personagem com a sua memória de guerra, que Ihe permitiu amadurecer a duras penas e sem preparo, e sua relação com as personagens ao seu redor, sendo sua mãe, seu pai e o ex-noivo. Dessa forma, a discussão se baseará numa leitura da obra El tiempo entre costuras, procurando levantar os principais elementos da trama que comprovam o papel da moda na construção da personagem e no enredo da obra, tendo como foco a análise da trama narrativa e da construção da personagem principal, Sira Quiroga, e de Rosalinda Powel Fox. 
Vale ressaltar que, das cinquenta e duas obras relacionadas na bibliografia apresentada no romance, nenhuma trata do assunto moda, portanto, a autora não aponta intencionalmente suas fontes bibliográficas ou testemunhais relacionadas aos conteúdos referentes a esse tema, ou acaba privilegiando outras. Isso parece trazer certo desequilibrio à recepção da obra, na medida em que a parte relacionada à moda parece bastante verossímil, enquanto aspectos relacionados às personagens reais presentes no romance, que deveriam trazer maior verossimilhança, parecem "inventadas", já que estas personagens/personalidades estão envoltas em situações, por vezes intimas, com as personagens ficcionais, sem comprovação histórica possível. Explicando melhor, a autora utiliza o recurso de trazer para a narrativa algumas personalidades históricas reais, que foram importantes para o contexto das guerras que envolveram a Espanha. Estas personalidades fazem parte da memória coletiva do país, sendo conhecidas por suas aparições públicas e biografias já publicadas a seu respeito. Quando levadas para a obra ficcional, acabam misturando na mente do leitor, de forma bastante sutil, esses dois universos, o do real e o do ficcional, principalmente quando algumas cenas com estas personalidades reais são inverossímeis. Mas também este não é o recorte deste artigo.

\section{Primeiros acontecimentos}

Sira Quiroga nasceu em 1911, num bairro típico de Madri, filha de mãe solteira, Dolores, costureira em um ateliê de alta-costura, o que também seria seu "destino natural" (p. 11) ${ }^{3}$, já que Sira entrou no ateliê como aprendiz do ofício aos 12 anos. Pouco frequentou a escola e nunca havia lido um livro na vida até sua mudança para Tetuán, justifica a narradora sobre seu quase nenhum conhecimento de mundo até então.

Não foi reconhecida pelo pai até próximo do estouro da Guerra Civil Espanhola, quando este percebeu que seria morto a qualquer momento e, em um instante de remorso, querendo então recuperar algo perdido no tempo, deu-lhe joias e dinheiro, além dos documentos da paternidade. Aos vinte anos estava pronta para se casar com Ignacio quando conheceu Ramiro, por quem se apaixona cegamente, abandonando tudo em Madri, incluindo sua mãe, e seguindo com ele até o Protetorado da Espanha no Marrocos 4 . Em poucos meses foi abandonada e roubada, sofrendo um aborto e ficando com inúmeras dívidas a quitar.

Essas breves cenas aqui descritas perfilam os momentos marcantes dessa primeira parte da narrativa. Para um livro de 477 páginas, passamos as primeiras 150 observando o quão inocente, chegando a ser ingênua, quase incapaz, Sira se mostra. É com espanto que o leitor a vê se deixar levar pela mãe, por Ignacio, por Ramiro, pelo delegado Vázquez, que a aprisiona após a fuga de Ramiro com seus pertences, deixando-Ihe a conta do hotel para pagar, dentre outras dívidas. $E$, ainda, por Candelária, uma muambeira que a abriga em sua pensão, coagida pelo delegado Vázquez, se deixando-se convencer a fazer o que outras pessoas acham que deve. 0 romance possui esse fio condutor, o do amadurecimento doloroso de uma jovem modista, em consequência do envolvimento amoroso com um homem mau-caráter e das experiências que passou durante as guerras seguidas nas quais seu país esteve envolvido.

Sira acaba sendo bem recebida na pousada de Candelária, mas a recuperação de tanta dor e decepção que sofreu parece irremediável. Até que acontece o "inesperado", como define a narradora: "Nunca poderia ter imaginado que a sensação de ter uma agulha nas mãos fosse tão gratificante" (p. 79). Sem ter o que fazer e querendo pelo menos ajudar nas despesas, Sira recolhe a roupa de cama da pousada e começa emendando rasgos, refazendo bainhas e arrematando franjas soltas: "A satisfação de costurar de novo foi tão grande que durante duas horas me devolveu a tempos mais felizes e conseguiu dissolver temporariamente o peso de chumbo de minhas próprias misérias" (p. 79). Assim, Dueñas propõe a recuperação da autoestima da personagem por meio de suas ações, em seu ofício ligado à moda.

Sira já havia percorrido toda Tetuá ${ }^{5}$ com Candelária em busca de emprego, mas em tempos de guerra ninguém tinha interesse em contratar funcionários, ninguém sabia o que estava por vir. Candelária havia desistido, mas, quando viu que Sira sabia 
costurar ficou encantada. Levou-a a seu armário e colocou todas as suas roupas sobre a cama: um casaco para fazer bainha, outro para virar a gola, dois dedos no quadril da saia... Depois de uma manhã para terminar o serviço, Sira se viu à frente de um corte de cheviote ${ }^{6}$ que Candelária havia comprado para um casaco, e esta Ihe perguntou: "Você dá conta?". Como Sira se mostrou capaz de costurar peças muito bem-feitas com o pouco que tinha, as duas pensaram em montar um ateliê que atendesse às clientes ricas da cidade, as estrangeiras que estavam ali refugiadas da guerra.

A venda de um carregamento de armas deixado na pensão por um hóspede desaparecido foi o que possibilitou a realização dos planos de montar o ateliê. Tendo os maçons como clientes, numa cena idealizada como bastante perigosa, Sira atravessa a cidade até a estação com as armas amarradas ao corpo por baixo dos trajes de moura (Fig. 1). Começa então uma relação direta da personagem com os acontecimentos do entorno da guerra, envolvendo o leitor em clima de suspense.

Figura 1 - Cena da série produzida pelo canal espanhol Antena 3. Sira, com as armas amarradas ao corpo, veste por cima o traje de moura.

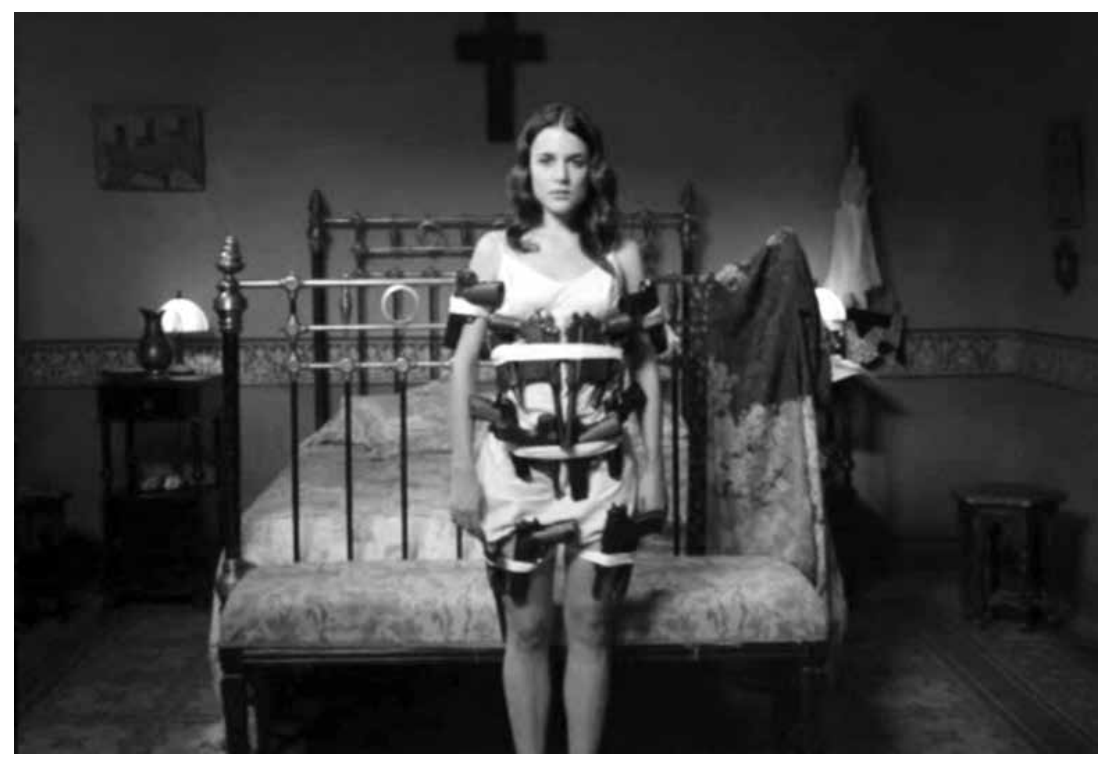

Fonte: https://vengoahablardemitele.wordpress.com/2013/10/30/el-tiempo-entre-costuras-alineacion-de-los-planetas/

Sira constrói um novo estilo para si por meio de um novo guarda-roupa e de uma nova postura perante as pessoas. Com a aparência de uma mulher forte e segura, esse será o disfarce para o negócio que deseja empreender, procurando submergir a muIher frágil que ainda sente ser, solitária diante do abandono e das perdas que sofreu. A narradora faz um paralelo entre Candelária e sua mãe, Dolores, como mulheres "corajosas e lutadoras, capazes de abrir caminho na vida com o pouco que a sorte lhes oferecesse". E diz: "Para mim e por elas, e por todas nós, eu tinha de lutar para que aquele negócio desse certo" (p. 119, grifo nosso). Há nessa citação uma comparação e uma afirmação que apontam para a intenção da autora em ressaltar a força das mulheres no período dos conflitos, que acaba ficando praticamente em segundo plano nos relatos históricos tradicionais, diante do posicionamento masculino de liderança, de supremacia nos assuntos de guerra.

\section{A presença feminina nas guerras}

No decorrer da narrativa, fica explícita a determinação da autora em delinear o posicionamento de várias mulheres no periodo entre a Guerra Civil Espanhola e o fim 
da Segunda Guerra Mundial. Ora elas aparecem como vitimas da situação, ora como heroínas capazes de vencer obstáculos aparentemente intransponiveis, ora como amantes manipuladoras de homens poderosos, capazes de influenciar o fio da história usando os artifícios que estão ao seu alcance.

Em seu estudo intitulado "La Mujer como Espía en El Tiempo Entre Costuras", Calon (2009, p. 5) apresenta sua tese:

Sira, la protagonista en El Tiempo entre Costuras, tiene que vivir una soledad voluntaria para poder desempeñarse en la función de espía. Ella tiene que alejarse de sus funciones "naturales" que la subordinan bajo la posición del hombre para poder desempeñarse en un rol clandestino, exterior y doble. Mediante su figura doble llega a conocerse mejor, y aprende que como sujeto no queda restringido a los límites del discurso, sino que es capaz de romperlos y superarlos. ${ }^{7}$

Podemos fazer uma aproximação da tese de Calon com os objetivos deste artigo se pensarmos que é por esse viés que Sira Quiroga poderá se tornar espiã. Calon, sob uma perspectiva feminista, reflete que a condição de espiã é dada à protagonista desde que se submeta a viver solitariamente, a abster-se, por períodos difíceis, do amor, do seu passado e de sua familia. Para defender sua tese, Calon analisa, entre outros pesquisadores, a feminista Judith Butler, que traz a teoria da performatividade do gênero, a ideia de que o problema da subordinação da mulher terá solução no que ela faz e não em como ela é. Calon pondera ainda sobre a identidade clandestina de Sira enquanto espiã, que é justamente onde Duenãs encontra a possibilidade de manifestação da mulher corajosa e poderosa que a personagem virá a se tornar dentro da narrativa, considerando que a espionagem sempre foi visualizada como uma função majoritariamente masculina.

Já Quétel (2009, Prefácio) reflete sobre a presença feminina na Segunda Guerra Mundial:

(...) as mulheres estão presentes em toda parte: vítimas no caminho do êxodo e sob as bombas, pacientes nas filas, inventivas e industriosas nas privações da vida cotidiana, trabalhadoras nas fábricas e nos campos durante a ausência dos homens. Em todos os países estiveram também uniformizadas: auxiliares na retaguarda, mas também na linha de frente. Combateram entre os guerrilheiros clandestinos e na Resistência, despertando muitas vezes até a admiração dos inimigos.

0 historiador diz ainda que foi preciso passar os anos 1970 para que surgissem do mundo anglo-saxão os women's studies, mais particularmente aqueles relacionados às mulheres na guerra. Atualmente, tanto estudos de historiadores quanto testemunhos atestam a importância do papel específico das mulheres nesses conflitos, sendo mais numerosos do que o imaginado. Mas através de fontes iconográficas da Segunda Guerra Mundial as aparições são "pontuais nos livros de história, ocupando espaço apenas casual ("as mulheres estavam lá, apesar de tudo"), em proveito da história das batalhas e de seus comandantes" (QUÉTEL, 2009, Prefácio) .

Nesse sentido, a literatura ficcional pode contribuir de forma a reelaborar essa presença. 0 tempo entre costuras é uma obra que estabelece uma relação entre o real e o ficcional, valendo-se do interesse do público leitor pelas memórias de guerras, pela curiosidade de saber e compreender os acontecimentos para além do que foi relatado pela história, mesmo que os fatos estejam de certa maneira ficcionalizados.

María Dueñas traz uma descrição da cenografia do romance extremamente detaIhista no que concerne aos atributos relacionados à moda e ao universo feminino nesse sentido. A descrição da montagem do ateliê de Sira em Tetuán é minuciosa, especificando a narradora que isso acontece "esporeada por Candelária" (p. 120). Sempre há um reforço no romance sobre esse aspecto de que a protagonista é conduzida pelas 
mãos de outras pessoas, não se fazendo ainda dona de seu destino, e que aos poucos ela vai aprendendo com os acontecimentos, desde os modelos de revistas de moda, os móveis, os tipos de tecidos, os detalhes da distribuição dos cômodos no apartamento alugado para esse fim. Sua primeira cliente de muitas que se seguiriam, uma alemã, Frau Heinz, escolhe chiffon, veludos e organzas para vestidos de noite e caxemira para as peças do dia, após examinar revistas e se decidir por modelos de Marcel Rochas e Nina Ricci. Aqui já aponta a autora como as clientes de Sira se importavam em aparecer luxuosamente vestidas, com requinte e "na moda", diante dos tecidos apontados, das revistas e estilistas escolhidos.

A autora detalha muitos desses momentos, chegando a filosofar sobre caracteristicas da moda:

Quando entrara no ateliê de dona Manuela, em meados dos anos 1920, predominavam as linhas soltas, a cintura baixa, os vestidos curtos para o dia e as túnicas lânguidas de cortes limpos e requintada simplicidade para a noite. A década de 1930 trouxe consigo mais comprimento, cinturas justas, cortes ao viés, ombreiras acentuadas e silhuetas voluptuosas. A moda mudava como mudam os tempos, e com eles as exigências da clientela e as artes das costureiras. (p. 125)

Outras clientes vieram, alemãs, italianas, espanholas esposas de empresários, judias ricas. Enquanto narra o dia a dia da protagonista, a autora introduz vários acontecimentos históricos relacionados à guerra, como quando Sira ouve pelo rádio:

(...) o governo da República havia se transferido para Valência e havia deixado o povo sozinho para defender Madri. Chegaram as Brigadas Internacionais para ajudar os republicanos, Hitler e Mussolini reconheceram a legitimidade de Franco, fuzilaram José Antônio [Primo de Rivera] na cadeia de Alicante (...) (p. 140) ${ }^{8}$

A protagonista reflete sobre a guerra: tão distante, tão presente (p. 140). Dueñas sustenta a narrativa reforçando o crescimento de Sira enquanto modista e apresentando detalhes da guerra, focando no envolvimento da personagem como alguém que está no entorno dos conflitos, como de certa forma esses conflitos atingem todas as pessoas; o medo, a solidão e o isolamento dos familiares impostos pela guerra.

\section{Rosalinda Powel Fox e o Delphos de Fortuny}

A autora traz Rosalinda Powel Fox, amante de Beigbeder, apresentada a Sira por uma italiana, apesar do sobrenome, Frau Langenheim ${ }^{9}$, e as coloca como grandes amigas. Esse envolvimento, que se tornará de cunho político além da amizade que manterão, será a ponte para que Sira se torne uma espiã, tomando essa função até o fim do romance, inicialmente sem muita certeza de desejar fazê-lo, assumindo-a como seu papel na guerra, a contribuição que pode dar tentando colaborar com seu país. Mais uma vez podemos retomar aqui ao estudo de Calon (2009), que aponta a transformação da mulher por meio da ação.

Tudo isso se dá com a mediação de sua profissão. É apenas como grande modista, ou couturier, que Sira consegue se aproximar de pessoas influentes sem chamar atenção para suas ações de espionagem. É com o disfarce de modista que Sira se passa por pessoa "não suspeita", que consegue adentrar recintos nos quais assuntos secretos e acordos são discutidos. Nesses ambientes, mulheres falando sobre moda, vestidos e penteados não parecem suspeitas, perigosas ou capazes de se interessar por assuntos políticos e comerciais envolvendo guerras. Assim, Sira é vista como uma bela mulher envolvida em frivolidades de mulheres e nunca como ameaça, sendo este um disfarce perfeito. 
Figura 2 - Cena da série produzida pelo canal espanhol Antena 3. Sira mostrando figurinos para sua cliente Rosalinda Powel Fox.

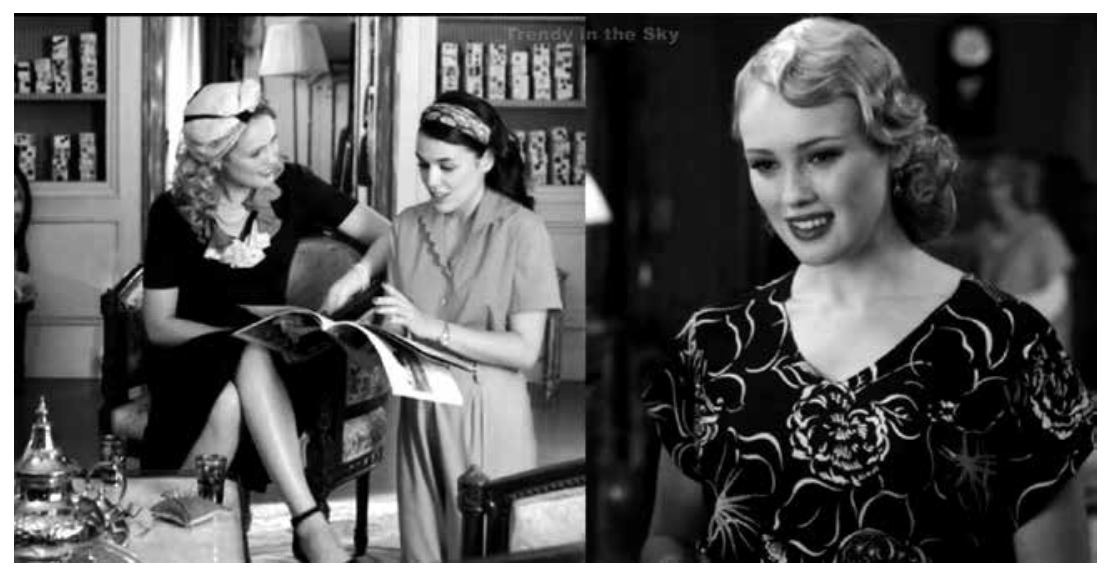

Fonte: http://neftis2o.blogspotcom.br/2014/09/vestuario-el-tiempo-entre-costuras.html

Rosalinda Powel Fox existiu como personagem real, foi espiã britânica e amante de Juan Luis Beigbeder, também uma personalidade histórica real. Rosalinda possuía convicções políticas bastante focadas em proteger seu país de um conflito com os alemães, sendo assim, um alvo da Gestapo e da Falange. Segundo Del Pino (2005), Rosalinda foi uma personalidade injustiçada até sua morte por ter sido praticamente esquecida. Sobre sua vida apenas pode ser encontrado um livro autobiográfico de memórias intitulado The Grass and the Asphalt, livro que consta na bibliografia apontada por María Dueñas em sua obra, aqui objeto de estudo.

São palavras de Del Pino, questionando sobre a participação de mulheres na função de espiãs:

Una cierta tradición machista ha dado lugar a que el espionaje sea percibido como algo de hombres y como una actividad relacionada con la guerra y los militares. La literatura y el cine han popularizado a algunas mujeres, desde Cleopatra a Mata-Hari. La última conocida, Alina de Romanones, autora de La espía de las botas rojas, como todas, se cuida de incluirse ella misma en un Gotha [cidade da Alemanha] en el que ni están todas las que son ni son todas las que están. Pero ¿qué fue la británica Rosalinda Fox espia, amante, o quizá la última aventurera romántica como aquéllas que desde finales del siglo XVIII y XIX recorrieron el mundo? (DEL PINO, 2005, p. 110) ${ }^{10}$

Ainda Del Pino (2005) diz que Rosalinda nasceu em princípios do século XX, filha de uma família inglesa que morava na Índia na época do Império, levada a se casar aos 16 anos com um comerciante rico de Calcutá. Após o nascimento de seu filho, contraiu uma doença grave e incurável, a tuberculose bovina, e foi enviada por seu marido à Inglaterra, depois morou em outros locais, em Tetuán e Madri, falecendo aos 96 anos, contra todos os prognósticos médicos que diziam que ela teria uma vida breve. Queremos ressaltar que esses e outros dados biográficos foram usados por Dueñas na construção da personagem Rosalinda Powel Fox.

É interessante perceber como a série criada pelo canal Antena 3 trouxe a público o interesse por esse período histórico. Reportagens e entrevistas podem ser encontradas na internet recontando a história, buscando fotos e fatos, informações. Pessoas que conheceram Rosalinda e podem contar um pouco de sua vida foram procuradas. Interessante ainda é observar o uso de imagens da série em contraposição às fotos reais de Rosalinda, fazendo um paralelo entre sua imagem real e a recriação da ficção feita por Dueñas." 
A autora cria uma cena que forja a amizade entre as duas mulheres, quando Rosalinda precisava ir a um evento importante com Beigbeder e não tinha o que vestir, pois sua bagagem havia ficado em seu destino anterior. Foi indicada à Sira por Frau Langenheim, como dissemos anteriormente, procurando algo pronto, sabendo que seria muito difícil confeccionar uma veste para o mesmo dia, poucas horas mais tarde. Então Sira diz que não tinha como ajudá-la, mas depois acaba tendo uma grande ideia, aceitando o desafio, e costura para ela um Delphos de Fortuny. 0 episódio se constitui como um momento de suspense na narrativa: Sira conseguirá fazer esse vestido? Que espécie de roupa é essa que pode ser costurada em três horas apenas?

Mas, além disso, o episódio ressalta características importantes de Rosalinda Powel Fox enquanto personagem do romance, paralelamente comparáveis com caracteristicas da pessoa real que foi Rosalinda Powel Fox, trazidas pela autora.

Para compreendermos o episódio e atestar a intenção de Dueñas em sustentar a profissão de Sira como estrutura fundamental no argumento do romance, faremos uma análise histórica do vestido. 0 Delphos de Fortuny foi um vestido criado e patenteado em 1909 pelo artista Mariano Fortuny Y Madrazo ${ }^{12}$, que ganhou fama mundial. 0 vestido possuía influência grega, advinda do chiton jônico, inspiração que Fortuny buscou num período em que visitou a Grécia, em 1906, quando desenvolveu o método de obtenção do plissado-ondulado da tela "único e inimitável" (MARTíNEZ, 2004, p. 5).

Figura 3 - 0 vestido Delphos de Fortuny, traje catalogado no Museo del Traje, em Madri, Espanha.

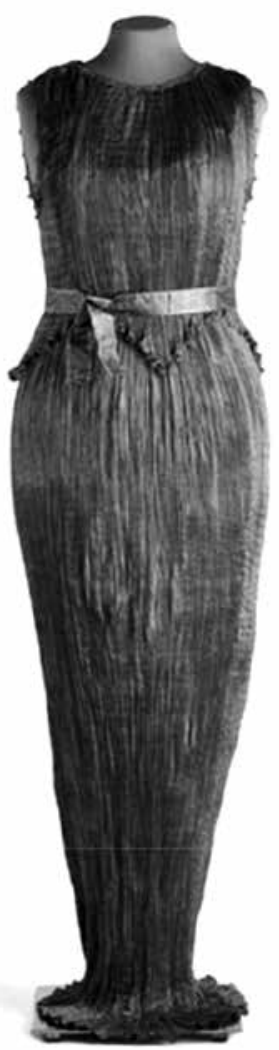


Sua estrutura de modelagem é de certa forma simples, visto que a montagem e o plissado retorcido são de fato o que trazem destaque à peça. Dessa forma, Sira consegue fazer um "falso Delphos" para Rosalinda, falso porque ela não utiliza a técnica descrita pelo artista por inteiro, mas reconstitui o aspecto final do famoso vestido.

0 que é bastante relevante em relação à análise da construção narrativa desse episódio é que a autora não parece escolher aleatoriamente o Delphos, mas pelo fato de este ser um vestido revolucionário, como a bela mulher que irá vesti-lo - Rosalinda Fox -, bem como sua participação nos acontecimentos referentes à Segunda Guerra Mundial tratados no romance.

Figura 4 - Cena da série produzida pelo canal espanhol Antena 3 mostrando Juan Luis Beigbeder e Rosalinda Powel Fox no vestido Delphos de Fortuny criado por Sira.

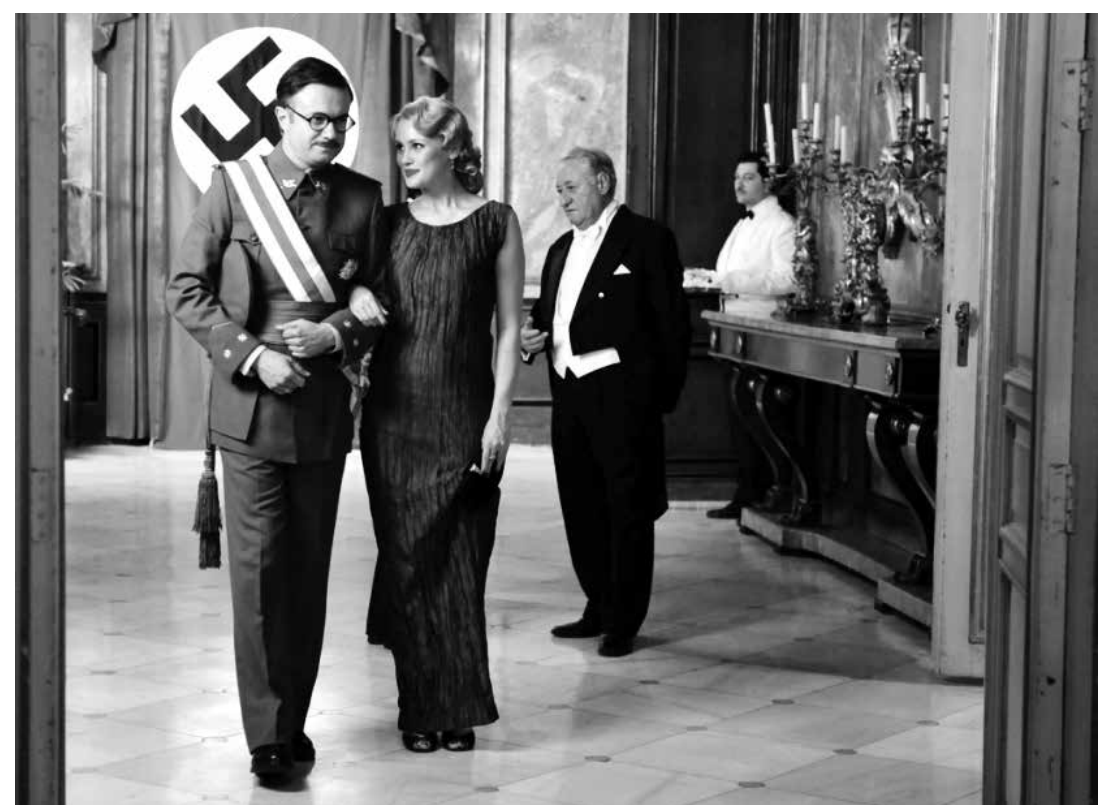

Fonte: http://eltiempoentrecosturaserie.blogspot.com.br/2013/11/las-fotos-del-tercer-capitulo-de-el.html

Quanto ao vestido, a independência de seus valores formais de criação, como apontam os estudos acerca da peça, vão de encontro à tirania da moda do século XIX, período anterior ao momento de sua criação, que manteve os corpos presos e deformados em anquinhas, espartilhos, saias volumosas de crinolina. Após esse período, havia a necessidade, o desejo "contra la tiranía de una moda que aprisionaba y deformaba los cuerpos y que pedian un vestido sano, racional, moderno y bello, que no ocultasen la belleza de las formas del cuerpo y revelasen sus extraordinarias posibilidades" (MARTíNEZ, 2004, p. 09) ${ }^{13}$. Decerto que não é um vestido a ser trajado por qualquer mulher, sendo que esse traço revolucionário influenciará de certa forma a aparência desta, seu estilo e sua forma de ser vista, como a autora descreve no romance (Fig. 4). Sobre sua influência nos pensamentos do amante, Rosalinda afirma:

- Eles têm razão em suas suposições porque eu, my dear, tenho a intenção de fazer tudo o que estiver a meu alcance para que Juan Luis [Beigbeder] estabeleça relações cordiais com meus compatriotas. Não posso suportar a ideia de que sua guerra [a Guerra Civil Espanhola] termine favoravelmente para o exército nacional, e que a Alemanha venha a ser a grande aliada do povo espanhol 
e a Grã-Bretanha uma potência inimiga. E vou fazer isso por duas razões. A primeira, por simples patriotismo sentimental: porque quero que a nação do homem que amo seja amiga de meu país. A segunda razão, however, é muito mais pragmática e objetiva: nós, ingleses, não confiamos nos nazistas, as coisas estão começando a ficar feias. Talvez seja um pouco arriscado falar de outra futura grande guerra europeia, mas nunca se sabe. $E$, se isso chegar a acontecer, eu gostaria que o seu país estivesse a nosso lado. (p. 193)

María Dueñas cunhou Rosalinda Powel Fox em sua narrativa, trazendo para a ficção traços da personalidade real histórica. É com grande desenvoltura que a personagem se move na narrativa, dirigindo seu carro com independência, transitando por todos os territórios com autoridade e fluidez. Consegue se adaptar rapidamente a todos os ambientes e se entrosa muito bem com as pessoas à sua volta, mostrando-se bem influente por meio de suas ações e aparições. A narrativa se engrandece com uma personagem que traz consigo a carga de uma história real, e, sendo colocada como grande amiga da personagem Sira, Rosalinda a contamina com essa mistura entre o real e 0 imaginado, diluindo as fronteiras na mente do leitor.

Memórias de guerra

É através de Rosalinda, já uma amiga conquistada, que Sira consegue trazer sua mãe ao Marrocos e também assim acaba conhecendo Marcus Logan, espião inglês disfarçado de jornalista, por quem viria a se apaixonar. Esse é um dos momentos da narrativa nos quais Sira se vê confrontada com a sua confortável situação longe do conflito de guerra. Diz que sua vida virou do avesso:

Ela chegou, esquelética, em uma tarde de nuvens, com as mãos vazias e a alma em frangalhos, tendo como bagagem apenas sua velha bolsa, o vestido que usava e um passaporte falso preso com um alfinete à alça do sutiã. Parecia ter envelhecido vinte anos: a magreza marcava as órbitas de seus olhos e os ossos das clavículas, e os primeiros fios de cabelo grisalho isolados que eu recordava já eram grandes mechas cinza. Entrou em minha casa como uma criança arrancada do sono no meio da noite: desorientada, confusa, alheia. Como se não entendesse que sua filha morava ali e que, a partir de então, seria também sua casa. (...) Nem um sorriso, nem uma lágrima e muito poucas palavras, isso foi tudo que houve. (p. 257)

Dolores chegou da frente de batalha que se tornou Madri. Não conseguiu contar o que passou, não chorou. Impossivel aqui não lembrar Walter Benjamin em seu texto "Experiência e pobreza", que pensa sobre a experiência da guerra:

Na época, já se podia notar que os combatentes voltavam silenciosos do campo de batalha. Mais pobres em experiências comunicáveis, e não mais ricos. (...) Porque nunca houve experiências mais radicalmente desmentidas que a experiência estratégica pela guerra de trincheiras, a experiência econômica pela inflação, a experiência do corpo pela fome, a experiência moral pelos governantes. (BENJAMIN, 2012, p. 124) 
Dolores chega com os sentidos à flor da pele, a fome, a presença tão próxima da morte, a tristeza, claramente perceptíveis em sua atitude alheia. E Sira percebe que essas vivências mudaram a mãe, visto que a pessoa forte e determinada havia se tornado vulnerável, bem como as suas experiências também a estavam mudando de forma oposta: "a pequena Sira já era uma mulher independente" (p. 258).

Num outro momento, quando Sira é abordada por Rosalinda e se torna Agente Especial do SOE, ela vai até a mãe buscando apoio e desejando uma negativa confortável: que fique e não vá se envolver em assuntos perigosos de guerra, que poderiam fazê-la morrer. 0 que Sira ouve da mãe:

- Quer meu conselho, filha? - perguntou. (...)

- Vá com eles, filha. Ajude, colabore. Nossa pobre Espanha não pode entrar em outra guerra, não tem mais forças.

- Mas, mãe...

Não me deixou prosseguir.

- Você não sabe o que é viver em guerra, Sira. Você não acordou, dia após dia, com o barulho das metralhadoras e a explosão dos morteiros. Você não comeu lentilhas com bicho mês após mês, não viveu um inverno sem pão, sem carvão e sem vidro nas janelas. Não conviveu com famílias desfeitas e crianças famintas. Não viu olhos cheios de ódio, de medo, ou das duas coisas ao mesmo tempo. A Espanha inteira está arrasada, ninguém mais tem forças para suportar de novo o mesmo pesadelo. A única coisa que o país pode fazer agora é chorar seus mortos e seguir em frente com o pouco que lhe resta. (p. 286)

Sira acaba concordando em colaborar como espiã indo para Madri, o terreno perigoso do qual queria fugir. Nesse momento foi indicada restrição de sua presença à periferia da cidade, isto é, devia ficar longe dos que conhecera antes. De outras formas também foi confrontada com essa questão. Seu ex-noivo, Ignacio, retorna à sua vida cinco anos depois, já em Madri, como funcionário da Direção Geral de Segurança do Ministério do Governo, responsável pela vigilância e acompanhamento dos estrangeiros que cruzavam as fronteiras, e Sira era um deles, já que foi para lá com seu novo nome, Arish Agoriuq, marroquina, como constava em seu passaporte. Ignacio segue Sira até seu novo ateliê em Madri e durante a discussão que ocorre quando se encontram frente a frente, ele a condena por sua omissão:

- Não gosto da pessoa em quem você se transformou, Ignacio - sussurrei atrás dele.

Ele riu com uma gargalhada amarga.

- E quem é você para me julgar? Por acaso se acha superior porque passou a guerra na África e voltou agora com ares de grande senhora? Pensa que é melhor que eu por acolher em sua casa ministros descarrilados e por se deixar adular com bombons enquanto os outros sofrem racionamento até de pão preto e ervilha?

- Eu o julgo porque me importo com você e lhe desejo o melhor - afirmei. Minha voz quase não saiu.

Ele respondeu com uma nova gargalhada. Mais amarga ainda que a anterior. Mais sincera também.

- Você não se importa com ninguém além de si mesma, Sira. Eu, mim, me, comigo. Eu trabalhei, eu sofri, eu paguei por meus erros: eu, eu, eu, eu. Ninguém mais lhe interessa, ninguém. Por acaso se incomodou em 
saber o que foi de sua gente depois da guerra? Alguma vez lhe ocorreu voltar a seu bairro vestindo suas roupas elegantes para perguntar por todos eles, para descobrir se alguém precisa de uma mão? Sabe o que foi de seus vizinhos e de suas amigas ao longo de todos esses anos? (p. 343)

Ignacio fala, até fazer Sira chorar, sobre o destino cruel de todos os seus vizinhos, alguns foram presos ou fuzilados, suas amigas de infância, as que se prostituíram e as que morreram em bombardeios, as desgraças de todos. Sentiu suas palavras como um soco na consciência, "como um punhado de sal jogado nos olhos abertos" (p. 343). E ainda a acusou de egoísta, de morar numa casa imensa onde "mastiga a solidão pelos cantos" (p. 346), alguém que renega suas origens. Sira foi aconselhada a não procurar seus vizinhos, mas também não manifestou interesse em saber algo sobre eles. Calon (2009, p. 14) reflete que a protagonista de 0 tempo entre costuras tem que ficar só para desempenhar sua função de espiã: "Ella adopta una soledad voluntaria; una soledad que, al mismo tiempo, es necesaria para ser libre. Sira únicamente puede hacerse cargo de su función como espía estando sola y quedándose sola."14

\section{Agente especial do SOE, codinome Sidi}

Aqui também a História serviu de pesquisa para Dueñas, que trouxe para sua narrativa o capitão Alan Hillgarth, soldado, escritor e espião britânico. No romance, Sira foi recrutada pelo Serviço Secreto Britânico através de Rosalinda, e sua missão especial teria base em Madri, sendo orientada pelo capitão Alan Hillgarth. A autora o coloca como encarregado de coordenar sigilosamente as atividades do SOE (Special Operations Executive), uma organização do Serviço Secreto "recém-criada por Churchill, destinada a assuntos relacionados com a guerra e à margem das operações de sempre" (p. 276), e do SIS (Secret Intelligence Service). Os intermediários na escolha desses agentes eram Rosalinda Fox e Juan Luis Beigbeder.

A indicação de Sira se deu pelo fato de que as mulheres dos altos oficiais nazistas se vestiam em Paris até que o exército alemão invadiu a França, em maio de 1940, sendo assim, a maioria das casas de costura fechou. Rosalinda explica: "poucos querem continuar trabalhando na Paris ocupada. A Maison Vionet, a Maison Chanel na rue Chambon, a loja de Schiaparelli na place Vendome: quase todos os grandes foram embora" (p. 278). Paris fica "out of question", nas palavras de Rosalinda, e "Berlim é muito longe. Ou se vestem em Madri, ou não vão estrear modelos na temporada que vai começar, o que para elas seria uma tragédia, porque a essência de sua vida nesses dias centra-se em uma vida social muito intensa" (p. 278).

Ainda havia a escassez de tecidos, já que as casas de moda que não fecharam acabaram destinando sua produção aos esforços de guerra e às necessidades básicas da população: "Com algodão fazem uniformes; com o linho, ataduras: qualquer tecido tem um destino mais prioritário que a moda" (p. 279). Sira poderia levar os tecidos de Tetuán, produtos argentinos e americanos, tendo ainda estoques de tecidos franceses, lãs inglesas, sedas indianas e chinesas. Ela poderia ser a "costureira da estação", capaz de oferecer o que as alemãs desejavam naquele momento: "ostentação, luxo, frivolidade absoluta, como se o mundo fosse um salão de baile, e não o sangrento campo de batalha em que eles o transformaram" (p. 279).

Sira ficaria responsável por ouvir toda a conversa gerada em seu ateliê e transcrevê-la em moldes de roupas, na forma de pontilhados de código Morse (como exemplo: ${ }^{*}-{ }^{*}-{ }_{-}{ }^{* * *}{ }^{*}$ ), que já se parecem com os sinais tracejados de um molde de roupas, de forma que ninguém suspeitaria se o material fosse pego durante a entrega 
nos locais indicados por Hillgarth. Conhecer a agenda social da comunidade alemã em Madri com detalhes era o principal interesse dos britânicos para que pudessem agir infiltrando outros agentes, buscando conhecer detalhes. Fica então detalhada ao leitor a função dos espiões de procurar saber detalhes da vida dos inimigos, de seus planos, para buscar alguma vantagem nas estratégias de guerra.

A autora demonstra grande destreza na elaboração de todo referencial relacionado à moda, dando detalhes pertinentes ao momento histórico, explicitando ter ocorrido uma pesquisa detalhada acerca desses dados. A montagem dos dois ateliês, os processos de execução de processos dentro destes, o tratamento com cliente, a estrutura do sistema da moda ainda claramente delineado por estações nesse período, enfim, vários documentos, livros, fontes devem ter sido consultados para a idealização desses descritivos no romance. E como argumento narrativo, realmente é de esperar que uma costureira, proprietária de um ateliê de alta-costura, obtivesse sucesso como espiã, tendo esse álibi perfeito.

Quando tudo parecia tranquilo em Madri, a missão em bom andamento, Sira foi convocada para uma nova missão de emergência em Lisboa. Não queria ir, visto que se sentia feliz em ter reencontrado seu pai nessa volta a Madri e por manter com ele uma reaproximação que "representava um ponto de luz na escuridão" (p. 373) de seus dias. Sira acaba cedendo, o sentimento que tinha nesse momento era o de que a "normalidade" em sua vida poderia voltar em qualquer lugar onde estivesse, e não dependia mais de seu passado ou de determinado lugar: "A normalidade não era nada além do que minha vontade, meu compromisso e minha palavra aceitassem que era, e, por isso, sempre estaria comigo" (p. 374).

Esse é o ponto da narrativa no qual a maturidade da protagonista é delineada pela autora. A trajetória de sujeição parece estar prestes a acabar, e a missão em Lisboa será para Sira como um teste de resistência final. Ela deveria ir a Lisboa supostamente para comprar materiais para seu ateliê: tecidos, aviamentos, acessórios. Mas deveria investigar a possível relação de um empresário português, Manuel da Silva, suspeito de estar fazendo alianças comerciais com os nazistas para acordos de exclusividade em minas de tungstênio, "mineral fundamental usado na fabricação de projéteis para a guerra" (p. 428), e Manuel seria o intermediador desses negócios com os mineiros de Beira.

Ao voltar da missão em Lisboa, encontra-se com Alan Hillgarth e reporta todos os acontecimentos da missão, na qual conseguiu todas as informações que precisava e outras além, com um detalhamento surpreendente. A personagem descreve a mudança em relação à sua trajetória de vida:

Embora tenha sido parco em palavras, sua atitude evidenciou que os dados que eu acabara de the oferecer formavam um copioso arsenal de informações valiosíssimas que deveriam ser analisadas detalhadamente por sua gente em Londres sem perder um segundo sequer. Aqueles detalhes iam disparar alarmes, quebrar alianças e reconduzir o rumo de centenas de operações. $E_{1}$ com isso, pressenti, a atitude do adido naval também mudaria radicalmente. Em seus olhos, eu havia visto nascer uma imagem diferente de mim: sua recruta mais temerária, a costureira inexperiente, de potencial promissor mas incerto, havia se transformado, da noite para o dia, em alguém capaz de resolver questões escabrosas com o arrojo e o rendimento de um profissional. Talvez carecesse de método e me faltassem conhecimentos técnicos; eu nem era uma deles devido a meu mundo, minha pátria e minha língua. Mas havia respondido muito melhor que o esperado e isso me punha em uma nova posição em sua escala. (p. 450)

Quase ao fim do romance, María Dueñas apresenta Sira já bastante modificada. Sente orgulho de si mesma pela capacidade de superação de tantos obstáculos aos quais foi submetida por todos à sua volta, sem preparação, sem treinamento, por sua 
resistência. E afirma se sentir orgulhosa por se "saber capaz de contribuir com um grão de areia para fazer daquele mundo de loucos um mundo melhor. Orgulhosa da mulher que me transformara" (p. 450).

\section{Considerações finais}

Ao final do romance, María Dueñas propõe uma conexão entre o presente e o passado de Sira. Que todas as acusações a que foi submetida, desde omissão a egoísmo por se manter num mundo confortável de luxo e conforto, sem viver diretamente os horrores das duas guerras nas quais seu país esteve envolvido, podiam ser suplantadas pelas ações e resultados obtidos em sua missão como espiã. Essa seria sua contribuição para com seu país em guerra. A moça inocente e submissa, descrita no decorrer da narrativa, transforma-se em uma mulher segura e capaz de gerir sua vida, seus negócios, seus amores. E que esse amadurecimento se deu por suas ações.

No Epílogo, a narradora mantém a obra aberta, um final que recupera todas as personagens, traçando seus destinos pelos anos que se seguiram, até aquele momento, no qual esta rememora seus anos de vida, afirmando que são suas recordações dos acontecimentos, mesmo que estes "rastros" se encontrem em muitos livros de história, arquivos e hemerotecas.

Retomamos aqui a epígrafe inicial deste artigo, que reproduz o último parágrafo do livro 0 tempo entre costuras, quando a narradora reflete sobre o seu destino e os de seus velhos conhecidos e amores, as outras personagens ficcionais da narrativa. Numa divagação do que poderia ou não ter acontecido, fica estabelecida a ideia da fluidez, e da não fixação dos destinos das personagens, já que estas não ficaram na história, e talvez nem sequer tenham existido; como que invisíveis, elas estavam por detrás da história. Há uma exposição irônica do caráter ficcional das personagens, fazendo uma relação com as pessoas reais que viveram durante os períodos de guerra e também não tiveram suas vidas conhecidas. Podemos pensar que a autora parece querer evidenciar assim que muitas pessoas estavam nos acontecimentos de guerra, mas grande parte morreu ou perdeu seus familiares nos conflitos ou no entorno deles, e muitas das que sobreviveram não tiveram suas histórias contadas, e suas memórias se perderam no encadeamento do tempo.

E, por fim, ressaltamos a importância da moda na construção da narrativa quando acionada pelo autor, que permitiu criar cenários e contribuir para a construção de aspectos interessantes para a trama ficcional e constituição das personagens. Dessa forma, a moda pode ser considerada como um componente importante para a criação ficcional da obra. 


\section{NOTAS}

[1] Este artigo foi produzido para o Seminário de Literatura Comparada: Literatura e Cinema de memória e guerra, disciplina de doutorado do Poslit FALE/UFMG, em 2015. A obra em questão foi apontada como integrante de uma lista de obras que abarcam $o$ assunto.

[2] Conforme noticiado em algumas mídias (abaixo estão indicadas duas fontes), María Dueñas foi acusada de plágio em 2013 por Patricia Martínez de Vicente, autora do livro Embassy y la inteligencia de Mambrú (2003), dizendo que a segunda parte do romance de María Dueñas possui dados e trechos quase íntegros de sua obra que não foram autorizados, apesar de seu nome constar na Nota de agradecimentos do romance de María Dueñas. Essa hipótese não foi trabalhada neste artigo. Em contato via Facebook com Patricia Martinez, de Vicente ela confirmou a informação. Também foi feito contato do mesmo modo com Maria Dueñas, mas não houve retorno. Ver mais em: <http://www.que.es/ultimas-noticias/sociedad/201310310800-tiempo-entre-costuras-plagio-mariaconthtml> e <https://es-es.facebook.com/antena3/posts/10151667275096298>.

${ }^{[3]}$ DUEÑAS, Maria. 0 tempo entre costuras. Tradução Sandra Martha Dolinsky. São Paulo: Editora Planeta do Brasil, 2012. A partir deste momento, todas as citações referentes à obra em análise serão apontadas apenas pelo número de página.

${ }^{[4]}$ Parte norte do Marrocos que ficou sob dominio espanhol entre 1912 e 1956 (data da independência).

${ }^{[5]}$ Entre 1912 e 1956, Tetuán foi a capital do Protetorado Espanhol de Marrocos. É uma cidade hispano-árabe.

[6] Tecido inglês de lã.

[7] Tradução da autora: Sira, a protagonista de 0 tempo entre costuras deve viver uma solidão voluntária para poder executar seu papel de espiã. Ela tem que se afastar de suas funções "naturais" e subordinadas ao homem para poder desempenhar um papel clandestino, estrangeiro e duplo. Com a sua figura dupla vem a conhecer-se melhor e aprende que como sujeito não se restringe aos limites do discurso, mas é capaz de quebrá-los e superá-los.

${ }^{[8]}$ Lider falangista, preso em Alicante, executado em 20 de novembro de 1936.

[9] "Seu pai havia sido embaixador italiano em Tânger e sua mãe era inglesa, mas ela havia assumido o sobrenome do marido, um engenheiro de minas mais velho, alto, calvo, renomado integrante da pequena, mas resoluta colônia alemã do Marrocos espanhol: um dos nazistas (...)" (p. 153).

[10] Tradução da autora: Certa tradição machista permitiu que a espionagem fosse percebida como algo de homens e como uma atividade relacionada com a guerra e os militares. A literatura e o cinema têm popularizado algumas mulheres, desde Cleópatra a Mata Hari. A última conhecida, Alina de Romanones, autora de La espía de las botas rojas, como todas, evita incluir-se em Gotha, onde nem todas as que o são foram abarcadas, e nem todas as inseridas nele o são. Mas quem foi a britânica Rosalinda Fox, espiã, amante, ou, talvez, a última aventureira romântica, como aquelas que desde o fim do século XVIII e XIX percorreram o mundo?

[11] Sugestão: <https://www.youtube.com/watch?v=TnkOX7uQUpY>.

[12] Nascido em Granada, em 1871, falecido em Venecia, 1949. Foi um grande desenhista espanhol, trabalhando em campos diversos como a pintura, gravura, fotografia, design, moda, iluminação e cenografia (MARTiNEZ, 2004).

${ }^{[13]}$ Tradução da autora: um vestido saudável, racional, moderno e bonito, não ocultando a beleza das formas do corpo e revelando as suas possibilidades extraordinárias.

${ }^{[14]}$ Tradução da autora: Ela adota uma solidão voluntária; uma solidão que, ao mesmo tempo, é necessária para estar livre. Sira só pode assumir o seu papel como uma espiã estando sozinha e solteira.

\section{REFERÊNCIAS}

BENJAMIN, Walter. Experiência e pobreza. In: BENJAMIN, Walter. Magia e técnica, arte e política: ensaios sobre literatura e história da cultura. Tradução Sérgio Paulo Rouanet. 8. ed. São Paulo: Brasiliense, 2012. P. 123-128. (Obras Escolhidas, v. I)

CALON, A.S.F. La Mujer como Espía en El Tiempo Entre Costuras: Una novela escrita por María Dueñas, 2009. (2013) Faculty of Humanities Theses. Eindwerkstuk Bacheloropleiding Spaanse Taal en Cultuur. (Bachelor thesis). University Utrecht. Disponivel em: <http://dspace.library.uu.nl/handle/1874/281528>. Acesso em: 21 jun. 2015.

DEL PINO, Domingo. Rosalinda Powell Fox, ¿espiá, amante, aventurera aristocrática? Con una vida llena de misterios, esta británica cambió, según muchos, el curso de la Segunda Guerra Mundial. AFKAR/ IDEAS, primavera de 2005, p. 110-112. Disponivel em: < http://www.iemed.org/observatori/arees-danalisi/ arxius-adjunts/afkar/afkar_ideas_6/Rosalinda_Powell_Fox>.Acesso em: 26 set. 2015.

DUEÑAS, María. El tiempo entre costuras. Madri: Temas de Hoy, 2009.

do Brasil, 2012.

O tempo entre costuras. Tradução Sandra Martha Dolinsky. São Paulo: Editora Planeta

MARTíNEZ, Maria del Mar Nicolás. Delphos de Fortuny: Los modelos más representativos de la exposición. Museo Del Traje. Departamento de difusion. Madri. 2004. Disponivel em: <http:// museodeltraje.mcu.es/popups/05-2004\%20pieza.pdf5. Acesso em: 11 abr. 2015.

QUÉELL, Claude. As mulheres na guerra: 1939-1945. Tradução Ciro Mioranza. São Paulo: Larousse do Brasil, 2009. 